\title{
White Tip Silver Needle (Slightly Fermented White Tea) Flavonoids Help Prevent Aging via Antioxidative and Anti-Inflammatory Effects
}

This article was published in the following Dove Press journal:

Drug Design, Development and Therapy

Chong $\mathrm{Li}^{\mathrm{I}-3, *}$
Jianchun $\mathrm{He}^{4, *}$
Yue Yang
Yuting Gou
Zhiying Wang
Hong Chen
Hin Zhao $^{1-3}$
Xin

'Chongqing Collaborative Innovation Center for Functional Food, Chongqing University of Education, Chongqing, 400067, People's Republic of China;

${ }^{2}$ Chongqing Engineering Research Center of Functional Food, Chongqing University of Education, Chongqing, 400067, People's Republic of China; ${ }^{3}$ Chongqing Engineering Laboratory for Research and Development of Functional Food, Chongqing University of Education, Chongqing, 400067, People's Republic of China; ${ }^{4}$ Department of Laboratory Medicine, Chongqing Dazu District People's Hospital, Chongqing, 402360, People's Republic of China; ${ }^{5}$ College of Biological and Chemical Engineering, Chongqing University of Education, Chongqing, 400067, People's Republic of China; ${ }^{6}$ School of Pharmacy, Heilongjiang University of Traditional Chinese Medicine, Harbin, I50040, People's Republic of China; ${ }^{7}$ The First

Department of Orthopaedic Surgery, Chongqing Traditional Chinese Medicine Hospital, Chongqing, 40002I, People's Republic of China

*These authors contributed equally to this work

\begin{abstract}
Aim: White tip silver needle, a slightly fermented white tea, is abundant in flavonoids, and it has great significance in terms of D-galactose/lipopolysaccharide-induced aging in mice.

Methods: We analyzed the antioxidant capacity of white tip silver needle flavonoids (WTSNF) in vitro, assessed the effects of WTSNF on organ indexes, pathological changes, liver function indexes, biochemical indicators, molecular biological indicators, and genes related to oxidation and inflammation.
\end{abstract}

Results: Ultra-high performance liquid chromatography-tandem mass spectrometry results showed that WTSNF contained baicalin, kaempferol, kaempferide, quercetin, isorhamnetin, lespenephryl, and rutin. WTSNF showed strong scavenging ability for both 1,1-diphenyl-2picrylhydrazyl (DPPH) and 2,2'-azino-bis (3-ethylbenzothiazoline-6-sulfonic acid) diammonium salt (ABTS) free radicals. Pathological analysis results showed that WTSNF reduced liver, kidney, and lung damage in mice with induced aging. In the serum and liver tissue, WTSNF effectively increased the antioxidant-related levels of superoxide dismutase, catalase, glutathione peroxidase, glutathione, and total antioxidant capacity and reduced the levels of aspartate aminotransferase, alanine aminotransferase, malondialdehyde and nitric oxide. WTSNF also reduced the inflammation-related levels of interleukin-6, interleukin-1 beta, tumor necrosis factor alpha (TNF $\alpha$ ), and interferon gamma (IFN- $\gamma$ ) and increased the levels of interleukin-10 and interleukin-12. Furthermore, WTSNF upregulated the mRNA expression levels of cupro-zinc superoxide dismutase, manganese superoxide dismutase, catalase, glutathione peroxidase, interleukin-10, neuronal nitric oxide synthase, endothelial nitric oxide synthase, nuclear factor erythroid 2-related factor, heme oxygenase 1, NAD(P)H dehydrogenase [quinone] 1, nuclear factor of kappa light polypeptide gene enhancer in B-cells inhibitor, alpha (IкB- $\alpha$ ), and thioredoxin, while it downregulated the mRNA expression levels of interleukin-6, interleukin-18, interleukin-1 beta, TNF $\alpha$, IFN- $\gamma$, inducible nitric oxide synthase, cyclooxygenase-2, and nuclear factor kappa-light chain-enhancer of activated B cells (NF-kB).

Conclusion: WTSNF is a high-quality natural product with antioxidative and anti-inflammatory properties that can inhibits D-galactose/lipopolysaccharide-induced aging in mice.

Keywords: white tip silver needle flavonoids, D-galactose/lipopolysaccharide, oxidation, inflammation

\section{Introduction}

Senility, which is an important issue facing today's increasingly aging society, mainly refers to the structural and functional degradation of biological cells, tissues, and organs. ${ }^{1}$ The aging process is accompanied by oxidation and inflammation.
Correspondence: Xin Zhao; Hong Chen Tel +86-23-6265-3650

Email zhaoxin@cque.edu.cn;

1528779302@qq.com 
Antioxidative and anti-inflammatory agents can delay the body's aging process. ${ }^{2}$ Animal models of natural aging have the disadvantages of long or uneven cycles, but aging in such models can be advanced through experimental means. D-galactose (D-Gal) is widely used to induce aging in animal models because it results in symptoms similar to those of natural aging. The mechanism of D-Gal-induced aging in animal models is not fully understood, but according to the metabolic theory of aging, aging is the result of metabolic disorders of the body. Disorders of glucose metabolism will inevitably lead to abnormal metabolic processes by the liver, kidney, brain, and other important organs and eventually lead to aging. Over a certain period of time, continuous D-Gal injections in animals can increase galactose concentrations in body cells, with galactose being reduced to D-galactitol under the catalysis of aldose reductase. D-galactitol cannot be further metabolized by cells and thus accumulates in cells, thereby affecting normal osmotic pressure, leading to cell swelling and dysfunction, and eventually aging. In addition, D-Gal is affected by galactose synthase, and free radicals produced during metabolism also lead to aging. ${ }^{3,4}$ Lipopolysaccharide (LPS) is an endotoxin that affect a variety of biological activities, induce non-specific immunity in the body, cause the synthesis and release of inflammatory cytokines, and damage the main system and organs of the host. Exogenous LPS increases the organ toxicity of D-Gal, and D-Gal causes hypersensitivity to LPS. The combined injection of D-Gal and LPS shortens the aging induction time and improves the stability of the aging model. 5

There has been increasing interest in the research on flavonoids because various flavonoids were found to have antioxidant free radicals, anti-inflammatory and anti-tumor activities, inhibit bacteria and viruses, and protect the cardiovascular system and liver. ${ }^{6}$ Tea is one of the most popular beverages in the world, and the flavonoids in tea also show many physiological activities. White tea, which is a micro-fermented tea, was originally produced in Fuding City, Fujian Province, China. Unlike the processing of other traditional Chinese teas, the processing of white tea is simple. Tea bud tips are picked, withered for a long time, and then processed by low heat drying. ${ }^{7}$ The more famous white teas in China include white peony, white tip silver needle, and longevity brow. White tip silver needle is named for its silver color, needle-like shape, and white hair-covered body. After brewing, the tea soup is a clear yellow-green color; the smell is fresh and tender; and the taste is light and sweet. White tea contains active ingredients, mainly polyphenols, flavonoids, caffeine, tea polysaccharides, and theanine. The antioxidative and anti-inflammatory effects of white tea are mainly derived from its abundant polyphenols and flavonoids. Flavonoids have regulatory effects in the body when it comes to glucose metabolism disorders; they inhibit the production of peroxides and peroxidation, inhibit a variety of harmful bacteria (Staphylococcus aureus, Vibrio cholerae, Escherichia coli, etc.), inhibit the production of pro-inflammatory factors induced by LPS, regulate immune cell function, and alleviate inflammation. ${ }^{8-10}$ Therefore, the purpose of this study is to explore the antioxidative and anti-inflammatory effects of white tip silver needle flavonoids (WTSNF) in mice with D-Gal/LPS-induced aging.

\section{Materials and Methods Preparation of White Tip Silver Needle Flavonoids}

The white tip silver needle (Fuding, Fujian, China) was chopped, ground, and dried at $60^{\circ} \mathrm{C}$. Then, $10 \mathrm{~g}$ of white tea powder was accurately weighed, and $250 \mathrm{~mL}$ of $70 \%$ ethanol was added. The filtrate was extracted for $60 \mathrm{~min}-$ utes in a water bath at $60^{\circ} \mathrm{C}$, and then it was extracted again. The extracted filtrates were combined, and WTSNF was obtained by using an N-1100 rotary evaporator (Eyela, Tokyo, Japan). The WTSNF was then put into a lowtemperature drying dish for later use.

\section{Ultra-High Performance Liquid Chromatography-Tandem Mass Spectrometry of White Tip Silver Needle Flavonoids}

Baicalin, kaempferol, kaempferide, quercetin, isorhamnetin, lespenephryl, and rutin (Beijing Putian Tongchuang Biotechnology Co., Ltd., Beijing, China) were each prepared into a $1 \mu \mathrm{g} / \mathrm{mL}$ working solution with $50 \%$ methanol-water. WTSNF was prepared into a $2 \mathrm{mg} / \mathrm{mL}$ sample solution with 50\% methanol-water and then passed through a $0.22-\mu \mathrm{m}$ membrane.

The PerkinElmer QSight ${ }^{\mathrm{TM}}$ LX50 ultra-high performance liquid chromatography (UHPLC) system was used to separate the WTSNF. The column model was the PerkinElmer Brownlee SPP C18 column $(2.1 \times 100 \mathrm{~mm}$, $2.7 \mu \mathrm{m})$. The column temperature was $40^{\circ} \mathrm{C}$. The injection 
volume was $5 \mu \mathrm{L}$. The mobile phase was $0.01 \%$ formic acid-water (A) and acetonitrile (B). The flow rate was $0.3 \mathrm{~mL} / \mathrm{min}$. The gradient elution procedure was: 0 to 1 minutes, $10 \% \mathrm{~B}$ (isocratic); 1 to 3 minutes, $10 \% \mathrm{~B}$ to $90 \%$ $\mathrm{B}$ (linear gradient); 3 to 5 minutes, $90 \% \mathrm{~B}$ (isocratic); 5 to 5.5 minutes, $90 \%$ B to $10 \% \mathrm{~B}$ (linear gradient); and 5.5 to 7 minutes, $10 \% \mathrm{~B}$ (isocratic).

The PerkinElmer QSight ${ }^{\mathrm{TM}} 210$ mass spectrometry (MS) system was used to detect the WTSNF. The electrospray ion source was used in the positive ion mode with multiple-reaction monitoring. The drying gas $\left(\mathrm{N}_{2}\right)$ parameter was $100 \mu \mathrm{L} / \mathrm{min}$. The hot source-induced desolvation temperature was $250^{\circ} \mathrm{C}$. The nebulizer gas parameter was $180 \mu \mathrm{L} / \mathrm{min}$. The electrospray voltage for Pos/Neg ionization was $5500 \mathrm{~V}$. The source temperature was $300^{\circ} \mathrm{C}$.

\section{Antioxidant Experiments in vitro}

First, $3.75 \mathrm{mg} / \mathrm{mL}$ of 2,2'-azino-bis(3-ethylbenzothiazoline-6-sulfonic acid) diammonium salt (ABTS) solution was mixed with $0.2 \mathrm{mg} / \mathrm{mL}$ of potassium persulfate solution in the same volume and then oxidized in the dark for 12 hours. Ethanol gradient dilution was then performed so the absorbance of the ABTS working solution at a wavelength of $732 \mathrm{~nm}$ was $0.7 \pm 0.02 .^{11} \mathrm{Next}, 0.5 \mathrm{~mL}$ of the WTSNF-ethanol solution at different concentrations (16 $\mu \mathrm{g} / \mathrm{mL}$ and $32 \mu \mathrm{g} / \mathrm{mL}$ ) was added to $4.0 \mathrm{~mL}$ of the ABTS working solution, shaken well for 10 seconds, and then kept in the dark for 10 minutes. Finally, $200 \mu \mathrm{L}$ of this mixture was added to a 96-well plate, and the absorbance at $732 \mathrm{~nm}$ was determined.

Similarly, $0.5 \mathrm{~mL}$ of the WTSNF-ethanol solution at different concentrations $(16 \mu \mathrm{g} / \mathrm{mL}$ and $32 \mu \mathrm{g} / \mathrm{mL})$ was added to $5.0 \mathrm{~mL}$ of the 1,1-diphenyl-2-picrylhydrazyl (DPPH) working solution $(25 \mu \mathrm{g} / \mathrm{mL})$, shaken for $10 \mathrm{sec}$ onds, and then kept in the dark for 30 minutes. Then, $200 \mu \mathrm{L}$ of this mixture was added to a 96-well plate, and the absorbance at $517 \mathrm{~nm}$ was determined. ${ }^{12}$

The experiments were repeated 3 times, and the results were averaged. The formula used to calculate the ABTS (or DPPH) free radical scavenging rate was as follows: ABTS (or DPPH) free radical scavenging rate $(\%)=(1-$ $\left.\left(\mathrm{A}_{\text {sample }}-\mathrm{A}_{\text {sample blank }}\right) /\left(\mathrm{A}_{\text {control}}-\mathrm{A}_{\text {control blank }}\right)\right) \times 100 \%$. In this formula, $\mathrm{A}_{\text {sample }}$ is the absorbance of the WTSNF solution after reaction with the ABTS (or DPPH) working solution; $A_{\text {sample blank }}$ is the absorbance of the WTSNF solution after reaction with anhydrous ethanol; $\mathrm{A}_{\text {control }}$ is the absorbance of the ABTS (or DPPH) solution; and $\mathrm{A}_{\text {control blank }}$ is the absorbance of anhydrous ethanol.

\section{Grouping of Experimental Mice and Establishment of the Aging Model}

Forty 6-week-old male Kunming mice (purchased from the experimental animal center of Chongqing Medical University, Chongqing, China) were exposed to a constant temperature $\left(25 \pm 2^{\circ} \mathrm{C}\right)$ and constant humidity $(50 \pm 5 \%)$ for 1 week. The mice were then divided into the normal group, model group, low-dose group, or high-dose group (10 mice in each group). During the experiment, all mice were given standard feed and drinking water. The model, low-dose, and high-dose groups were given daily intraperitoneal injections of D-Gal/LPS (30 mg/kg·BW, $3 \mu \mathrm{g} / \mathrm{kg} \cdot \mathrm{BW})$. In addition, the low-dose and high-dose groups were given oral administration of different concentrations of WTSNF $(150 \mathrm{mg} / \mathrm{kg}$ and $300 \mathrm{mg} / \mathrm{kg}$, respectively) daily. The experiment lasted for 8 weeks. The experimental design is shown in Figure 1. This study was approved by the Ethics Committee of the Collaborative Innovation Center for Functional Food, Education University of Education (202003049B), and followed the national standard of the People's Republic of China (GB/T 35892-2018) laboratory animal guidelines for ethical review of animal welfare.

\section{Collection of Mouse Serum and Tissue Samples}

On the last day of the experiment, the mice were fasted for 18 hours, the blood samples were taken through retro orbital plexus. The mice were then euthanized by using carbon dioxide. The blood was cryopreserved at $4^{\circ} \mathrm{C}$ for 0.5 hours, until it coagulated. It was then centrifuged at $4^{\circ} \mathrm{C}$ and $4000 \mathrm{r} / \mathrm{min}$ for 15 minutes to obtain the upper serum, which was stored at $-80^{\circ} \mathrm{C}$ for future use. After dissection, the heart, liver, spleen, lung, and kidney of each mouse were taken and weighed accurately. Tissues from parts of the liver, kidney, and lung were fixed with $10 \%$ formalin solution. The remaining tissues were frozen in liquid nitrogen and stored at $-80^{\circ} \mathrm{C}$ for subsequent experiments.

\section{Organ Index}

The heart, liver, spleen, lung, and kidney tissues were washed with sterile water, dried with filter paper, and weighed accurately to calculate the organ index. The following formula was used for this calculation: organ index $(\mathrm{mg} / \mathrm{g})=$ organ weight $(\mathrm{mg}) /$ body weight $(\mathrm{g})$. 
Normal diet

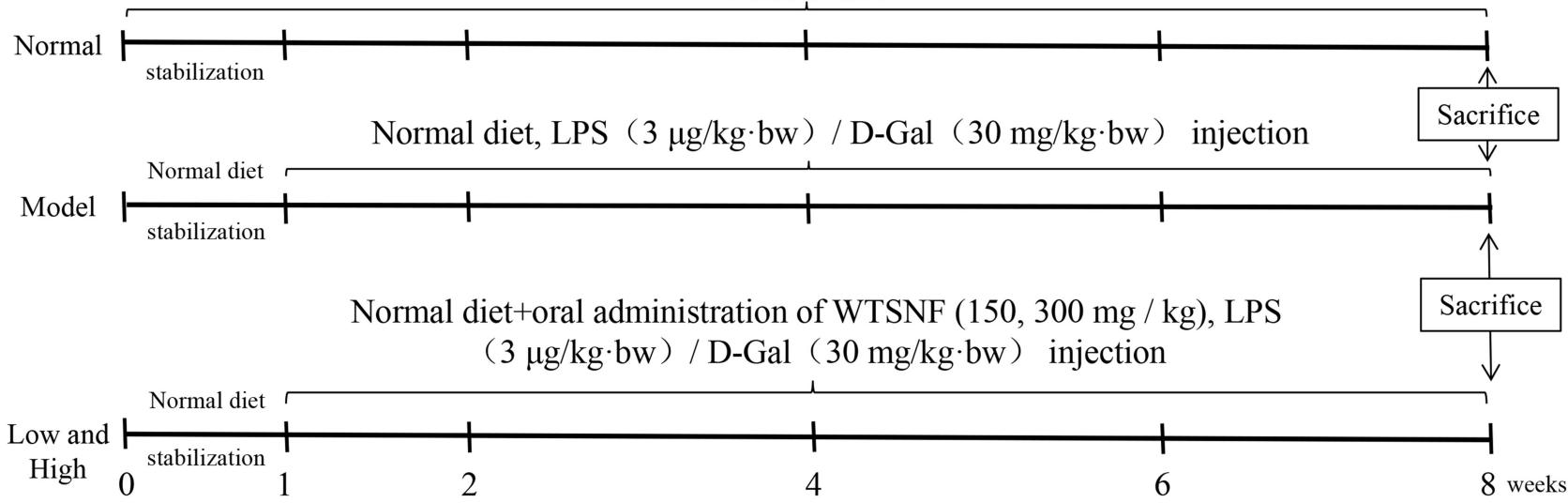

Figure I Establishment of aging mouse model.

Abbreviation: WTSNF, white tip silver needle flavonoids.

\section{Histological Observations}

After the liver, kidney, and lung tissues were fixed with $10 \%$ formalin for 24 hours, they were embedded in paraffin and stained with hematoxylin eosin. Pathological changes were observed under a microscope (Olympus, Tokyo, Japan).

\section{Biochemical Indexes in the Serum and Liver of Mice}

Alanine aminotransferase (ALT), aspartate aminotransferase (AST), malondialdehyde (MDA), catalase (CAT), glutathione (GSH), glutathione peroxidase (GSH-Px), total antioxidant capacity (T-AOC), nitric oxide (NO), and superoxide dismutase (SOD) levels in the serum and liver tissue of mice were determined by using test kits (Jiancheng Institute of Bioengineering, Nanjing City, Jiangsu Province, China).

\section{Cytokine Levels in the Serum and Liver of Mice}

Tumor necrosis factor alpha (TNF $\alpha$ ), interferon gamma (IFN$\gamma$ ), interleukin-1 beta (IL-1 $\beta$ ), interleukin-6 (IL-6), interleukin-12 (IL-12), and interleukin-10 (IL-10) levels in the serum and liver were determined by using enzyme-linked immunosorbent assay kits (ABCAM, Cambridge, MA, USA).

\section{Gene Expression Levels in the Liver of} Mice (Quantitative Real-Time Reverse Transcription Polymerase Chain Reaction Assay)

Liver tissue was homogenized, and total RNA was extracted with TRIzol ${ }^{\mathrm{TM}}$ reagent (Thermo Fisher Scientific, Inc., Waltham, MA, USA). The concentration and purity of the total RNA were detected by spectrophotometry and the total RNA concentration was diluted to $1 \mu \mathrm{g} / \mu \mathrm{L}$. According to the recommendation of the reagent manufacturer (Thermo Fisher Scientific), the total RNA was reverse transcribed to obtain the cDNA template. Finally, a mixture of $1 \mu \mathrm{L}$ of the cDNA template, $10 \mu \mathrm{L}$ of SYBR Green PCR Master Mix (Thermo Fisher Scientific), $1 \mu \mathrm{L}$ of upstream and downstream primers (Thermo Fisher Scientific), and $7 \mu \mathrm{L}$ of sterile distilled water was amplified. The reaction conditions were as follows: 60 seconds at $95^{\circ} \mathrm{C}, 15$ seconds at $95^{\circ} \mathrm{C}, 30$ seconds at $55^{\circ} \mathrm{C}$, and 35 seconds at $72^{\circ} \mathrm{C}$. The StepOnePlus real-time polymerase chain reaction system (Thermo Fisher Scientific) was used. $\beta$-actin was used as the internal reference. RNA was detected at $95^{\circ} \mathrm{C}$ for 30 seconds and $55^{\circ} \mathrm{C}$ for 35 seconds. The expression levels of related genes were calculated by using the $2^{-\Delta \Delta \mathrm{CT}}$ method. ${ }^{13}$ The primer sequences are shown in Table 1.

\section{Statistical Analysis}

All experiments were repeated 3 times, and the data were expressed as means \pm standard deviations. The data were analyzed by using SPSS 20.0 statistical software (SPSS Inc., Chicago, IL, USA). One-way analysis of variance and Duncan's multiple range tests were used, with $P<0.05$ indicating statistical significance.

\section{Results}

\section{Optimization of Mass Spectrometry} Conditions and Composition Analysis of White Tip Silver Needle Flavonoids

Seven standard samples were directly implanted into the ion source through an injection pump (flow rate, $20 \mu \mathrm{m} /$ 
Table I Primer Sequences in This Study

\begin{tabular}{|c|c|}
\hline Gene Name & Sequence \\
\hline Cu/Zn-SOD & $\begin{array}{l}\text { Forward: 5'-AACCAGTTGTGTTGTGAGGAC-3' } \\
\text { Reverse: 5'-CCACCATGTTTCTTAGAGTGAGG-3' }\end{array}$ \\
\hline$M n-S O D$ & $\begin{array}{l}\text { Forward: 5'-CAGACCTGCCTTACGACTATGG-3' } \\
\text { Reverse: 5'-CTCGGTGGCGTTGAGATTGTT-3' }\end{array}$ \\
\hline CAT & $\begin{array}{l}\text { Forward: 5'-GGAGGCGGGAACCCAATAG-3' } \\
\text { Reverse: 5'-GTGTGCCATCTCGTCAGTGAA-3' }\end{array}$ \\
\hline$G S H-P x$ & $\begin{array}{l}\text { Forward: 5'-GTCGGTGTATGCCTTCTCGG-3' } \\
\text { Reverse: 5'-AGAGAGACGCGACATTCTCAAT-3' }\end{array}$ \\
\hline IL- 10 & $\begin{array}{l}\text { Forward: 5'-CTTACTGACTGGCATGAGGATCA-3' } \\
\text { Reverse: 5'-GCAGCTCTAGGAGCATGTGG-3' }\end{array}$ \\
\hline IL-6 & $\begin{array}{l}\text { Forward: 5'-CTGCAAGAGACTTCCATCCAG-3' } \\
\text { Reverse: 5'-AGTGGTATAGACAGGTCTGTTGG-3' }\end{array}$ \\
\hline$T N F-\alpha$ & $\begin{array}{l}\text { Forward: 5'-CAGGCGGTGCCTATGTCTC-3' } \\
\text { Reverse: 5'-CGATCACCCCGAAGTTCAGTAG-3' }\end{array}$ \\
\hline$I F N-\gamma$ & $\begin{array}{l}\text { Forward: 5'-GGCCTAGCTCTGAGACAATGAAC-3' } \\
\text { Reverse: 5'-TGACCTCAAACTTGGCAATACTC-3' }\end{array}$ \\
\hline$I L-I \beta$ & $\begin{array}{l}\text { Forward: 5'-GAAATGCCACCTTTTGACAGTG-3' } \\
\text { Reverse: 5'-TGGATGCTCTCATCAGGACAG-3' }\end{array}$ \\
\hline IL-18 & $\begin{array}{l}\text { Forward: 5'-GACTCTTGCGTCAACTTCAAGG-3' } \\
\text { Reverse: 5'-CAGGCTGTCTTTTGTCAACGA-3' }\end{array}$ \\
\hline $\mathrm{nNOS}$ & $\begin{array}{l}\text { Forward: 5'-CCCAACGTCATTTCTGTCCGT-3' } \\
\text { Reverse: 5'-TCTACCAGGGGCCGATCATT-3' }\end{array}$ \\
\hline iNOS & $\begin{array}{l}\text { Forward: 5'-GTTCTCAGCCCAACAATACAAGA-3' } \\
\text { Reverse: 5'-GTGGACGGGTCGATGTCAC-3' }\end{array}$ \\
\hline eNOS & $\begin{array}{l}\text { Forward: 5'-TCAGCCATCACAGTGTTCCC-3' } \\
\text { Reverse: 5'-ATAGCCCGCATAGCGTATCAG-3' }\end{array}$ \\
\hline COX-2 & $\begin{array}{l}\text { Forward: 5'-TTCCAATCCATGTCAAAACCGT-3' } \\
\text { Reverse: 5'-AGTCCGGGTACAGTCACACTT-3' }\end{array}$ \\
\hline$N F-\kappa B$ & $\begin{array}{l}\text { Forward: 5'-ATGGCAGACGATGATCCCTAC-3' } \\
\text { Reverse: 5'-CGGAATCGAAATCCCCTCTGTT-3' }\end{array}$ \\
\hline $\mathrm{Nrf2}$ & $\begin{array}{l}\text { Forward: 5'-TAGATGACCATGAGTCGCTTGC-3' } \\
\text { Reverse: 5'-GCCAAACTTGCTCCATGTCC-3' }\end{array}$ \\
\hline $\mathrm{HO}-\mathrm{I}$ & $\begin{array}{l}\text { Forward: 5'-GATAGAGCGCAACAAGCAGAA-3' } \\
\text { Reverse: 5'-CAGTGAGGCCCATACCAGAAG-3' }\end{array}$ \\
\hline NQOI & $\begin{array}{l}\text { Forward: 5'-AGGATGGGAGGTACTCGAATC-3' } \\
\text { Reverse: 5'-TGCTAGAGATGACTCGGAAGG-3' }\end{array}$ \\
\hline$I K B-\alpha$ & $\begin{array}{l}\text { Forward: 5'-CGCGGGATGGCCTCAAGAAGGA-3' } \\
\text { Reverse: 5'-GCCAAGTGCAGGAACGAGTCT-3' }\end{array}$ \\
\hline $\operatorname{Trx}$ & $\begin{array}{l}\text { Forward: 5'-TGCTACGTGGTGTGGACCTTGC-3' } \\
\text { Reverse: 5'-ACCGGAGAACTCCCCCACCT-3' }\end{array}$ \\
\hline$\beta$-Actin & $\begin{array}{l}\text { Forward: 5'-GAGAAAATCTGGCACCACACCT-3' } \\
\text { Reverse: 5'- GCACAGCCTGGATAGCAACGTA-3' }\end{array}$ \\
\hline
\end{tabular}

min; mass concentration, $1 \mu \mathrm{g} / \mathrm{mL}$ ). In the positive ionization mode, the parent ion peak was obtained by first-order $\mathrm{MS}$, then the target ion underwent secondary scanning to obtain fragment ions. The two fragment ions with the highest responses were selected for qualitative and quantitative analyses, and the relevant parameters were optimized by using the multiple-reaction monitoring mode (Table 2).

Based on the optimized MS parameters, the 7 compounds in the WTSNF sample were qualitatively and quantitatively analyzed, including lespenephryl (peak 1, $2.1 \mathrm{~min}$ ), rutin (peak 2, $2.352 \mathrm{~min}$ ), kaempferol (peak 3, $2.394 \mathrm{~min}$ ), quercetin (peak 4, $2.478 \mathrm{~min}$ ), kaempferide (peak 5, $2.52 \mathrm{~min}$ ), isorhamnetin (peak 6, $2.898 \mathrm{~min}$ ), and baicalein (peak 7, $3.024 \mathrm{~min}$ ). The detailed results are shown in Figure 2 and Table 3.

\section{Antioxidant Effects of White Tip Silver Needle Flavonoids in vitro}

The scavenging ability of the WTSNF on ABTS and DPPH radicals (Table 4) were assessed at concentrations of 16 and $32 \mu \mathrm{g} / \mathrm{mL}$, demonstrating ABTS radical scavenging activity values of $12.7 \pm 1.47 \%, 50.6 \pm 1.08 \%$, and DPPH radical scavenging activity values of 25.07 $\pm 1.66 \%, 62.51 \pm 0.8 \%$, respectively. WTSNF had significant scavenging effects on ABTS and DPPH free radicals, and with increased WTSNF concentrations, the scavenging effects were better $(P<0.05)$.

\section{Organ Index in Mice}

Long-term, low-dose D-Gal/LPS stimulation caused organs weight loss and decrease of the main organ index in the model group $(P<0.05$, Table 5). WTSNF treatment inhibited this condition, and the organ index of the heart, liver, spleen, lung, and kidney were improved to varying degrees.

\section{Histological Observations}

As shown in Figure 3, in the normal group, the liver cells were arranged in a regular, clear, radial distribution. In addition, the lung tissue structure was normal, the alveolar wall was intact, the alveolar cavity was clearly visible, and no obvious edema was found in the alveoli or interstitial areas of the lung. Further, the glomerulus and renal tubules were in order, and the renal tubular epithelial cells were clear. In the model group, the liver cells were disordered, the boundaries 
Table 2 Mass Spectrum Parameters in This Study

\begin{tabular}{|c|c|c|c|c|c|}
\hline No. & Component & Parent Ion $(\mathrm{m} / \mathrm{z})$ & Daughter Ion (m/z) & Collision Energy/V & Entrance Voltage/V \\
\hline \multirow[t]{2}{*}{ I } & \multirow[t]{2}{*}{ Baicalein } & \multirow[t]{2}{*}{271.1} & $123.1^{*}$ & -51 & 11 \\
\hline & & & 253.1 & -90 & 12 \\
\hline \multirow[t]{2}{*}{2} & \multirow[t]{2}{*}{ Kaempferol } & \multirow[t]{2}{*}{287.1} & $153.1^{*}$ & -51 & 63 \\
\hline & & & 213.1 & -52 & 47 \\
\hline \multirow[t]{2}{*}{3} & \multirow[t]{2}{*}{ Kaempferide } & \multirow[t]{2}{*}{301.1} & 286.1 & -98 & 16 \\
\hline & & & $165.1^{*}$ & -55 & 20 \\
\hline \multirow[t]{2}{*}{4} & \multirow[t]{2}{*}{ Quercetin } & \multirow[t]{2}{*}{303.2} & $229.1^{*}$ & -51 & 55 \\
\hline & & & 257.1 & -97 & 59 \\
\hline \multirow[t]{2}{*}{5} & \multirow[t]{2}{*}{ Isorhamnetin } & \multirow[t]{2}{*}{318.3} & $88.1^{*}$ & -51 & 24 \\
\hline & & & 256.4 & -98 & 2 \\
\hline \multirow[t]{2}{*}{6} & \multirow[t]{2}{*}{ Lespenephryl } & \multirow[t]{2}{*}{579.3} & $287.1^{*}$ & -52 & 8 \\
\hline & & & 433.1 & -95 & 13 \\
\hline \multirow[t]{2}{*}{7} & \multirow[t]{2}{*}{ Rutin } & \multirow[t]{2}{*}{611.2} & $303.1^{*}$ & -82 & 14 \\
\hline & & & 465.2 & -99 & 19 \\
\hline
\end{tabular}

Note: *Quantitative ion.

were unclear, there was inflammatory cell infiltration, and some of the hepatocytes were necrotic. In addition, the alveolar structure was damaged, and there was alveolar wall edema, pulmonary interstitial thickening, alveolar cavity reduction, etc. Further, the renal tubules showed vacuolar degeneration, and there was glomerular reduction, often accompanied by interstitial edema and inflammatory infiltration of fine cells. Compared with those of the model group, the structures of the liver, lung, and renal tissues of the WTSNF treatment groups were improved, and the infiltration of inflammatory cells decreased to different degrees.

\section{Liver Function Indexes in the Serum of Mice}

AST and ALT levels in the serum of the model group were higher than those in the normal group (Table 6). WTSNF treatment reduced the levels of AST and ALT in the serum, and the effects of high-dose WTSNF were more significant than those of low-dose WTSNF $(P<0.05)$.

\section{Oxidation-Related Indexes in the Serum and Liver of Mice \\ SOD, CAT, GSH, GSH-Px, and T-AOC levels in the serum} and liver tissue of the model group were significantly lower than those in the normal group, while MDA and

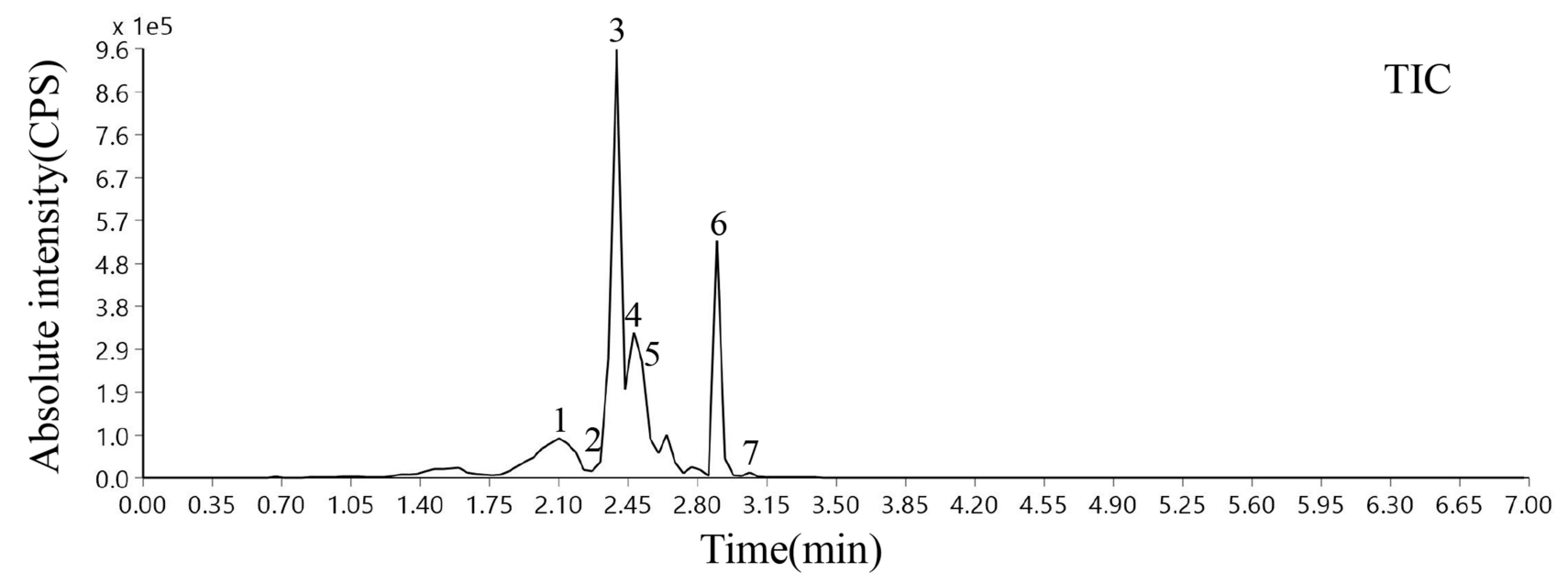

Figure 2 Total ion chromatography of WTSNF. I: baicalein; 2: kaempferol; 3: kaempferide; 4: quercetin; 5: isorhamnetin; 6: lespenephryl; 7: rutin. 
Table 3 Relative Molecular Mass, Molecular Formula, Structure, Retention Time and Content of Seven Flavonoids in WTSNF

\begin{tabular}{|c|c|c|c|c|c|c|}
\hline No. & Component & $\begin{array}{c}\text { Relative Molecular } \\
\text { Mass }\end{array}$ & $\begin{array}{l}\text { Molecular } \\
\text { Formula }\end{array}$ & $\begin{array}{c}\text { Structural } \\
\text { Formula }\end{array}$ & $\begin{array}{c}\text { Retention Time } \\
\text { (Min) }\end{array}$ & $\begin{array}{c}\text { Contents } \\
(\mathrm{ng} / \mathrm{mL})\end{array}$ \\
\hline 1 & Lespenephryl & 578.5187 & $\mathrm{C}_{27} \mathrm{H}_{30} \mathrm{O}_{14}$ & & 2.1 & 1987.047 \\
\hline 2 & Rutin & 610.51 & $\mathrm{C}_{27} \mathrm{H}_{30} \mathrm{O}_{16}$ & & 2.352 & 582.509 \\
\hline 3 & Kaempferol & 286.24 & $\mathrm{C}_{15} \mathrm{H}_{10} \mathrm{O}_{6}$ & & 2.394 & 2038.636 \\
\hline 4 & Quercetin & 302.24 & $\mathrm{C}_{15} \mathrm{H}_{10} \mathrm{O}_{7}$ & & 2.478 & 1111.259 \\
\hline 5 & Kaempferide & 300.2629 & $\mathrm{C}_{16} \mathrm{H}_{12} \mathrm{O}_{6}$ & & 2.52 & 11.90 \\
\hline 6 & Isorhamnetin & 316.26 & $\mathrm{C}_{16} \mathrm{H}_{12} \mathrm{O}_{7}$ & & 2.898 & $7|2.69|$ \\
\hline 7 & Baicalein & 270.24 & $\mathrm{C}_{15} \mathrm{H}_{10} \mathrm{O}_{5}$ & & 3.024 & 17.94 \\
\hline
\end{tabular}

Table 4 Clearance of ABTS and DPPH by WTSNF

\begin{tabular}{|l|c|c|}
\hline Groups & Low & High \\
\hline ABTS & $12.7 \pm 1.47^{\mathrm{bc}}$ & $50.6 \pm 1.08^{\mathrm{a}}$ \\
DPPH & $25.07 \pm 1.66^{\mathrm{b}}$ & $62.51 \pm 0.8^{\mathrm{a}}$ \\
\hline
\end{tabular}

Notes: Low: WTSNF with concentration $16 \mu \mathrm{g} / \mathrm{mL}$; High: WTSNF with concentration $32 \mu \mathrm{g} / \mathrm{mL}$. a,b Mean values with different letters in the same line are significantly different $(p<0.05)$, as determined by Duncan's multiple range test. 'Values presented are the mean \pm standard deviation (SD) of different organ coefficient.

NO levels were significantly higher in the model group than in the normal group $(P<0.05$, Figure 4). After WTSNF treatment, the decreased levels of SOD, CAT, GSH-Px, and T-AOC caused by D-Gal/LPS, as well as the increased levels of NO and MDA caused by D-Gal/ LPS, were effectively inhibited, and the high concentration of WTSNF was more effective than the low concentration.

\section{Cytokine Levels in the Serum and Liver of Mice}

IL-10 and IL-12 levels in the serum and liver tissue of the model group were significantly lower than those in the normal group, while IL-1 $\beta$, IL-6, TNF $\alpha$, and IFN- $\gamma$ levels were significantly higher in the model group than in the normal group $(P<0.05$, Figure 5). WTSNF treatment effectively reduced IL- $1 \beta$, IL- 6 , TNF $\alpha$, and IFN- $\gamma$ levels and increased IL-10 and IL-12 levels in the serum and liver tissue of injured mice, and high-dose WTSNF had better effects than low-dose WTSNF.

\section{Gene Expression Levels of $\mathrm{Cu} / \mathrm{Zn}-\mathrm{SOD}$, Mn-SOD, CAT, and GSH-Px in the Liver of Mice}

The mRNA expression levels of cupro-zinc superoxide dismutase ( $\mathrm{Cu} / \mathrm{Zn}-\mathrm{SOD})$, manganese superoxide dismutase (Mn-SOD), CAT, and GSH-Px in the liver tissue of the model group were significantly lower than those in the normal group $(P<0.05$, Figure 6$)$. WTSNF significantly upregulated the mRNA expression levels of Mn-SOD, $\mathrm{Cu} /$ Zn-SOD, CAT, and GSH-Px in the liver of the model group, and the effects of high-dose WTSNF were better than those of low-dose WTSNF. 
Table 5 Main Organ Index Treated with D-Gal/LPS

\begin{tabular}{|l|c|c|c|c|c|}
\hline Groups & Heart & Lung & Liver & Spleen & Kidney \\
\hline Normal & $5.78 \pm 0.25^{\mathrm{a}}$ & $5.21 \pm 0.13^{\mathrm{bc}}$ & $40.01 \pm 0.74^{\mathrm{a}}$ & $7.58 \pm 0.24^{\mathrm{a}}$ & $13.15 \pm 0.26^{\mathrm{a}}$ \\
Model & $4.83 \pm 0.19^{\mathrm{c}}$ & $4.59 \pm 0.11^{\mathrm{c}}$ & $38.04 \pm 0.31^{\mathrm{c}}$ & $6.06 \pm 0.25^{\mathrm{c}}$ & $11.88 \pm 0.29^{\mathrm{bc}}$ \\
Low & $5.24 \pm 0.16^{\mathrm{b}}$ & $5.4 \pm 0.12^{\mathrm{ab}}$ & $39.19 \pm 0.46^{\mathrm{ab}}$ & $6.8 \pm 0.27^{\mathrm{b}}$ & $12.27 \pm 0.25^{\mathrm{b}}$ \\
High & $5.6 \pm 0.21^{\mathrm{a}}$ & $5.7 \pm 0.18^{\mathrm{a}}$ & $40.09 \pm 0.82^{\mathrm{a}}$ & $8.11 \pm 0.38^{\mathrm{a}}$ & $13.41 \pm 0.43^{\mathrm{a}}$ \\
\hline
\end{tabular}

Notes: Model: mice treated with D-Gal (30 mg/kg bw)/LPS (3 $\mu \mathrm{g} / \mathrm{kg}$ bw); Low: mice treated with WTSNF (I50 mg/kg); High: mice treated with WTSNF (300 mg/kg). Values are mean \pm standard deviation (SD). ${ }^{a-c}$ Mean values with different letters in the same column are significantly different $(p<0.05)$, as determined by Duncan's multiple range test.

Gene Expression Levels of IL-I $\beta$, IL-6, ILI0, IL-18, TNF $\alpha$, and IFN- $\gamma$ in the Liver of Mice

The mRNA expression levels of IL-1 $\beta$, IL-6, TNF $\alpha$, IL-18, and IFN- $\gamma$ in the liver tissue of the model group were significantly higher than those in the normal group, while the mRNA expression levels of IL-10 were significantly lower in the model group than in the normal group $(P<$ 0.05 , Figure 7). WTSNF effectively reduced the mRNA expression levels of IL- $1 \beta$, IL-6, TNF $\alpha$, IL-18, and IFN- $\gamma$ and increased the mRNA expression levels of IL-10, and high-dose WTSNF had better effects than low-dose WTSNF.

\section{Gene Expression Levels of nNOS, eNOS, iNOS, and COX-2 in the Liver of Mice}

The mRNA expression levels of neuronal nitric oxide synthase (nNOS) and endothelial nitric oxide synthase (eNOS) in the liver tissue of the model group were significantly lower than those in the normal group, while the mRNA expression levels of inducible nitric oxide synthase (iNOS) and cyclooxygenase-2 (COX-2) were higher in the model group than in the normal group $(P<0.05$, Figure 8$)$. WTSNF inhibited the enhanced expression levels of iNOS and COX-2 and reduced the expression levels of nNOS and eNOS, and high-dose WTSNF had better effects than low-dose WTSNF.

\section{Gene Expression Levels of Nrf2, HO-I, NQOI, NF- $\kappa B$, I $\kappa B-\alpha$, and Trx in the Liver of Mice}

The mRNA expression levels of nuclear factor erythroid 2related factor (Nrf2), heme oxygenase 1 ( $\mathrm{HO}-1), \mathrm{NAD}(\mathrm{P})$ $\mathrm{H}$ dehydrogenase [quinone] 1 (NQO1), nuclear factor of kappa light polypeptide gene enhancer in B-cells inhibitor,

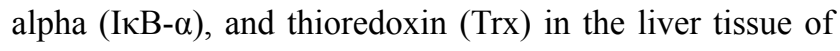
the model group were significantly lower than those in the other 3 groups, while the mRNA expression levels of NF$\kappa \mathrm{B}$ were higher in the model group than in the other 3 groups $(P<0.05$, Figure 9$)$. WTSNF enhanced the expression levels of Nrf2, HO-1, NQO1, IкB- $\alpha$, and Trx and inhibited the expression levels of NF- $\kappa \mathrm{B}$, and high-dose WTSNF had better effects than low-dose WTSNF.

\section{Discussion}

Plant flavonoids has many pharmacological and healthcare effects, such as free radical scavenging, antioxidation, anti-virus, weight loss, lipid-lowering, anti-mutation, and anti-cancer effects, especially the important aspect of antibacterial activity of the molecules of vegetable origin and in particular of the flavonoids with also antioxidant activity against multi-drug resistant strains increasingly present in the clinical setting, but the specific mechanism of action is not yet clear. ${ }^{14,15}$ The main active components in white tea include polyphenols, amino acids, caffeine, and flavonoids. Due to its simple processing, white tea's content of functional ingredients is significantly higher compared to other types of tea. ${ }^{8,16}$ In this study, WTSNF was analyzed by using UHPLC-MS/MS. ${ }^{17}$ The results showed that WTSNF contained 7 compounds: baicalin, kaempferol, kaempferide, quercetin, isorhamnetin, lespenephryl, and rutin. Kaempferol is widely found in various fruits and vegetables, and of the 7 compounds, kaempferol was found to have the highest content in WTSNF. Kaempferol has antioxidative, anti-inflammatory, and anti-cancer effects, plus it can prevent and treat atherosclerosis and diabetes, as well as inhibit protein kinase activity and immunosuppression. ${ }^{18}$ Quercetin is a flavanol with a variety of biological properties. It can complex or trap free radicals to prevent lipid peroxidation in the body, plus it has anti-bacterial an anti-inflammatory effects, and it can prevent diabetic complications and inhibit tumors. ${ }^{19}$ Rutin can terminate the chain reaction of free radicals, inhibit the peroxidation of polyunsaturated fatty acids on biofilms, remove lipid peroxidation products, reduce 

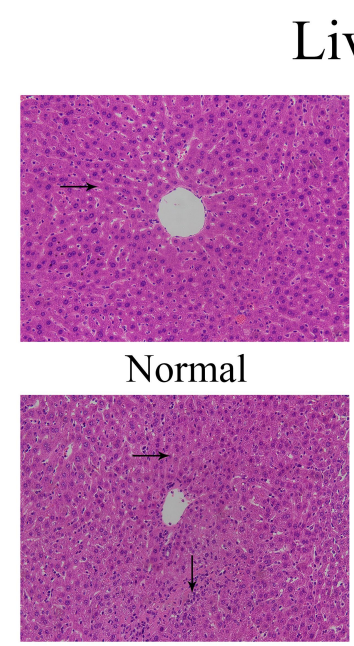

Low

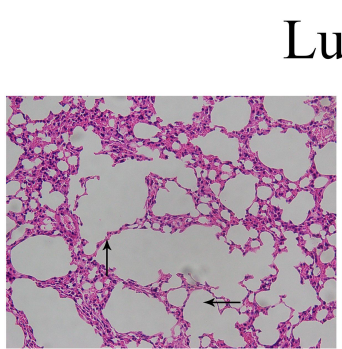

Normal

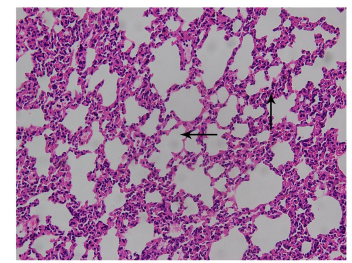

Low

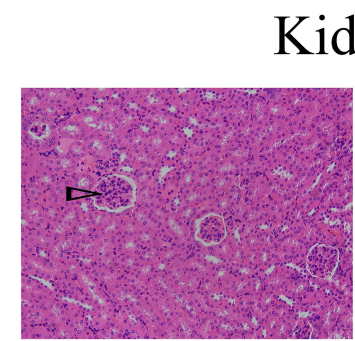

Normal

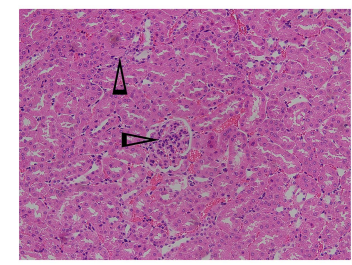

Low

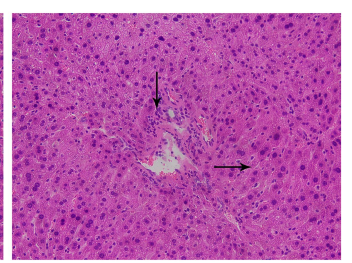

Model

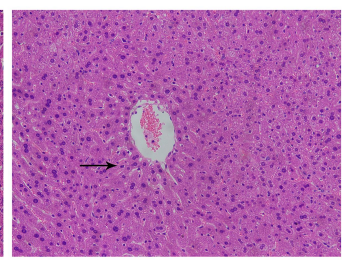

High

Lung

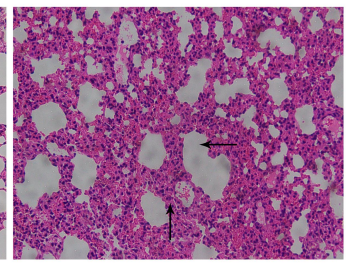

Model

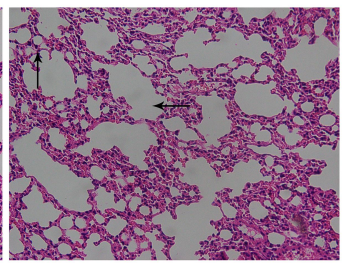

High

Kidney

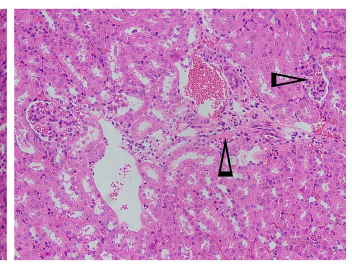

Model

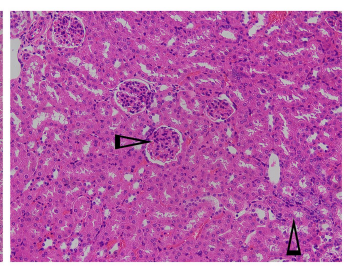

High
Figure 3 Histological observation of liver, lung and kidney in mice. Model: mice treated with D-Gal $(30 \mathrm{mg} / \mathrm{kg}$ bw)/LPS $(3 \mu \mathrm{g} / \mathrm{kg}$ bw); Low: mice treated with WTSNF (I50 mg/kg); High: mice treated with WTSNF (300 mg/kg). $\rightarrow$ Liver cord;

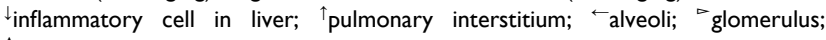
$\Delta_{\text {inflammatory cell in kidney. }}$
Table 6 Levels of AST and ALT in Serum of Mice

\begin{tabular}{|l|c|c|}
\hline Groups & AST(U/L) & ALT(U/L) \\
\hline Normal & $5.87 \pm 0.68^{\mathrm{de}}$ & $1.2 \pm 0.19^{\mathrm{c}}$ \\
Model & $10.92 \pm 0.57^{\mathrm{a}}$ & $2.45 \pm 0.11^{\mathrm{a}}$ \\
Low & $8.59 \pm 0.74^{\mathrm{b}}$ & $1.88 \pm 0.16^{\mathrm{b}}$ \\
High & $6.5 \pm 0.65^{\mathrm{c}}$ & $0.42 \pm 0.10^{\mathrm{d}}$ \\
\hline
\end{tabular}

Notes: Model: mice treated with D-Gal $(30 \mathrm{mg} / \mathrm{kg} \cdot \mathrm{bw}) / \mathrm{LPS}(3 \mu \mathrm{g} / \mathrm{kg} \cdot \mathrm{bw})$; Low: mice treated with WTSNF (I50 mg/kg); High: mice treated with WTSNF (300 mg/ $\mathrm{kg})$. ${ }^{\mathrm{e}}$ Values are mean \pm standard deviation (SD). ${ }^{\mathrm{a}-\mathrm{d}}$ Mean values with different letters in the same column are significantly different $(p<0.05)$, as determined by Duncan's multiple range test.

Abbreviations: ALT, alanine aminotransferase; AST, aspartate aminotransferase.

inflammation, and maintain vascular elasticity and permeability together with vitamin $C .^{20}$ Lespenephryl has antioxidative, anti-inflammatory, blood sugar-lowering, antifatigue, fever-reducing, and detoxification effects, and it can reduce swelling and pain. ${ }^{21}$ As a powerful antioxidant, isorhamnetin can scavenge oxygen free radicals to prevent cell and tissue damage caused by oxidation. It has a variety of biological properties, such as antioxidative, anti-tumor, anti-inflammatory, anti-viral, and anti-allergy effects, and it participates in immune function regulation, especially in terms of protecting the cardiovascular system. ${ }^{22}$ Baicalin and kaempferide were found in lower amounts in WTSNF, but they also have significant pharmacological effects, such as antioxidative, anti-inflammatory, and anti-tumor effects. ${ }^{23,24}$ WTSNF contains all these active compounds, which may be why it inhibits the oxidative damage and inflammation of organs caused by D-Gal/LPS.

In the in vitro antioxidant experiments, ABTS was oxidized to generate the stable blue-green cationic radical ABTS + . The antioxidant components in WTSNF can react with $\mathrm{ABTS} \cdot+$, thereby causing reaction systems to fade. ${ }^{11}$ DPPH is a very stable nitrogen-centered free radical that can capture other free radicals. DPPH solution appears dark purple and turns light yellow after being combined with WTSNF. ${ }^{12}$ Through the in vitro antioxidant experiments, we proved that WTSNF has strong scavenging effects on both ABTS and DPPH free radicals.

Long-term chronic oxidative stress and inflammation in the body lead to aging, which is a complex biological process mediated by multiple factors, eventually causing apoptosis and necrosis of cells in various organs, and its causes are also various. ${ }^{25}$ Excessive injection of D-Gal can cause glucose metabolism disorders, increase peroxidation reactions in the body, and produce free radicals that 


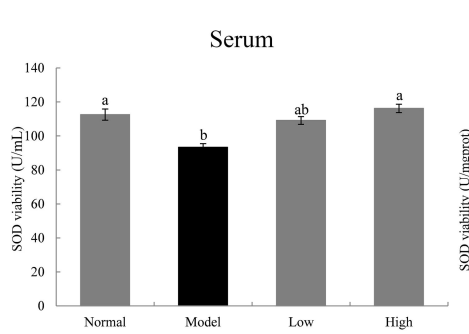

Liver
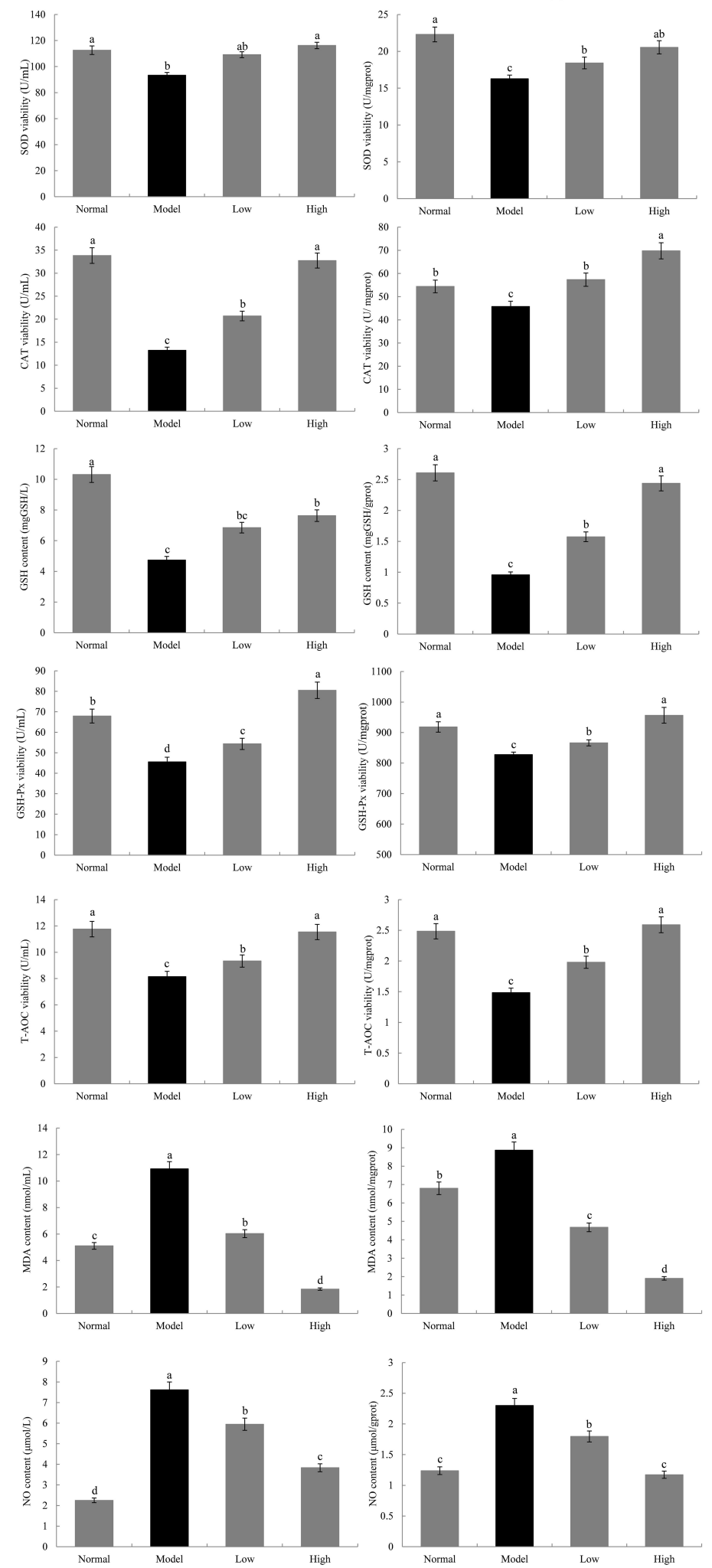

Figure 4 Levels of SOD, CAT, GSH, GSH-Px, T-AOC, MDA and NO in serum and liver in mice. Model: mice treated with D-Gal ( $30 \mathrm{mg} / \mathrm{kg}$ bw)/LPS ( $3 \mu \mathrm{gg} / \mathrm{kg}$ bw); Low: mice treated with WTSNF (150 mg/kg); High: mice treated with WTSNF $(300 \mathrm{mg} / \mathrm{kg}) .{ }^{\mathrm{a}-\mathrm{d}}$ Mean values with different letters in the same bar graph are significantly different $(p<0.05)$ according to Duncan's multiple range test. 


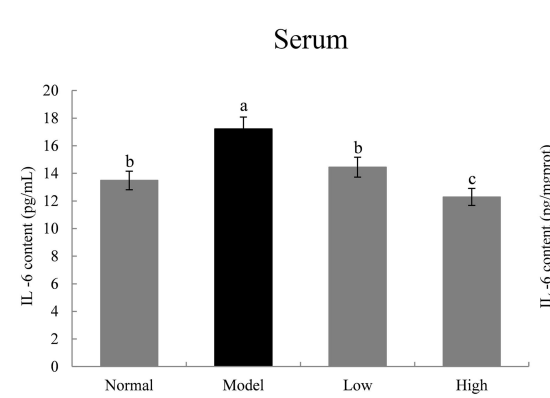

Liver
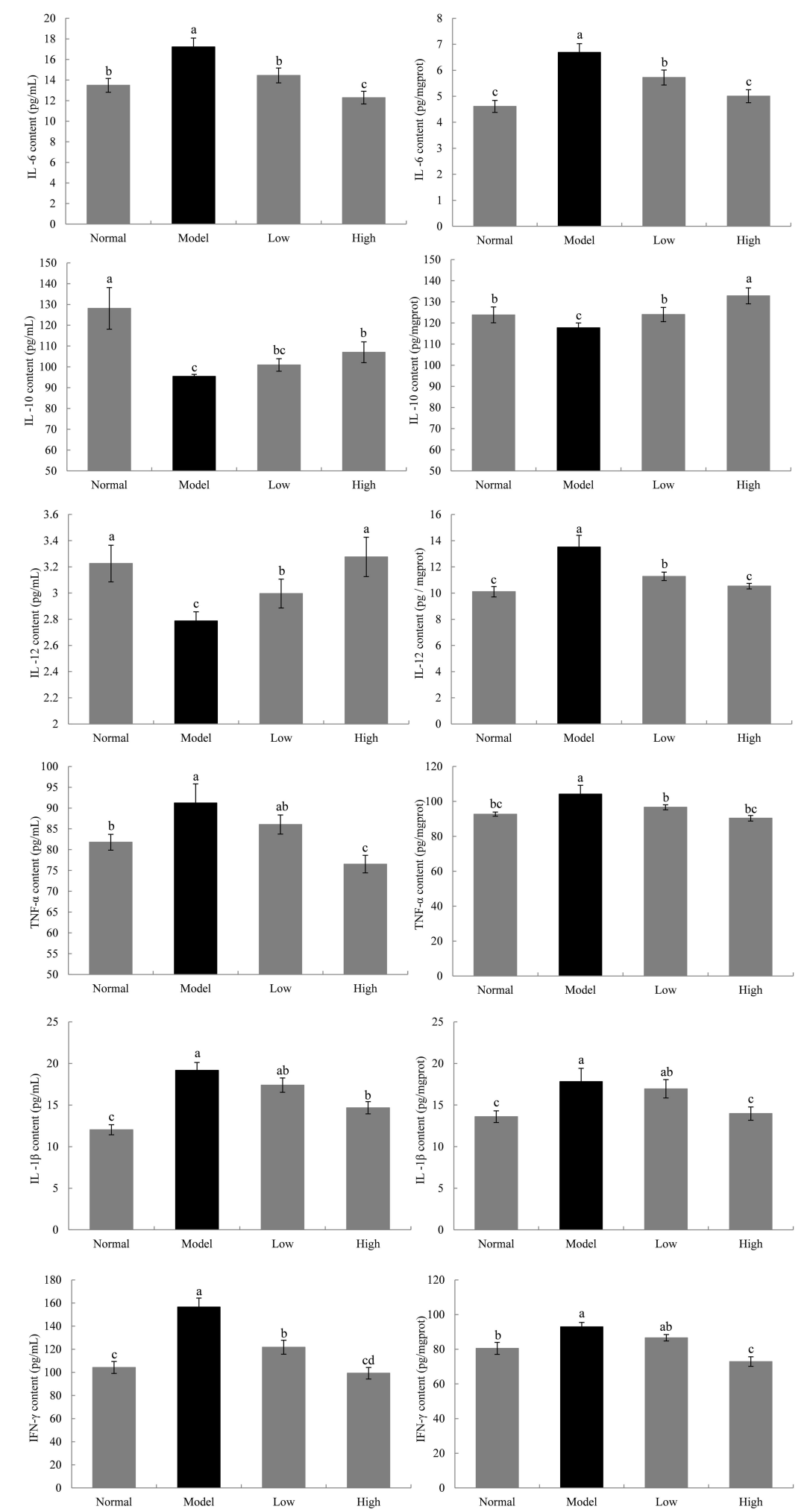

Figure 5 Levels of IL-6, IL-I0, IL-I $\beta$, IL- I2, TNF- $\alpha$ and IFN- $\gamma$ in serum and liver in mice. Model: mice treated with D-Gal (30 mg/kg bw)/LPS (3 $\mu g / k g$ bw); Low: mice treated with WTSNF (150 mg/kg); High: mice treated with WTSNF $(300 \mathrm{mg} / \mathrm{kg}) .{ }^{\mathrm{a}-\mathrm{d}}$ Mean values with different letters in the same bar graph are significantly different $(p<0.05)$ according to Duncan's multiple range test. 

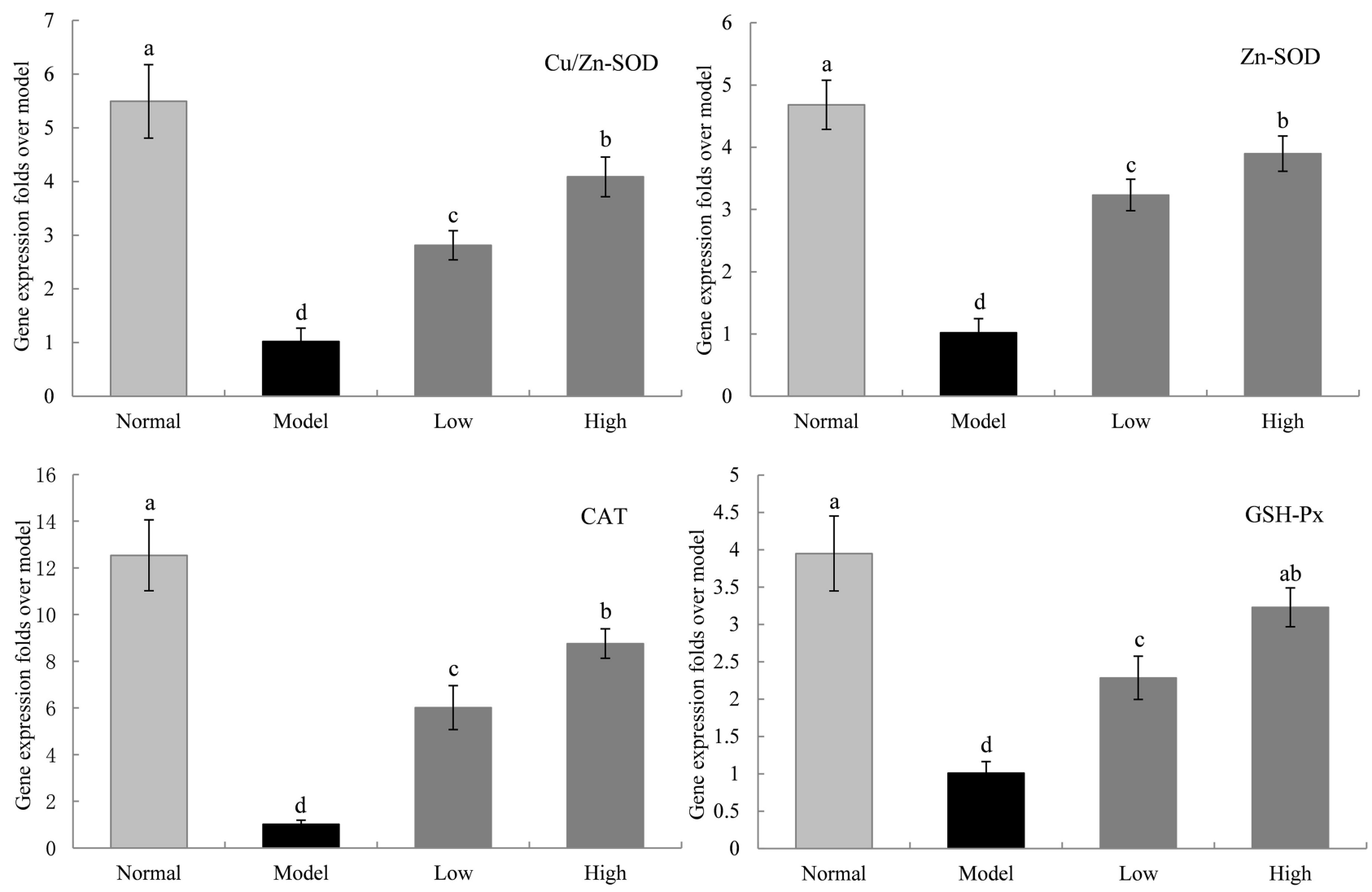

Figure 6 The Cu/Zn-SOD, Mn-SOD, CAT and GSH-Px mRNA expression in liver of mice. Model: mice treated with D-Gal (30 mg/kg bw)/LPS (3 $\mu$ g/kg bw); Low: mice treated with WTSNF (150 mg/kg); High: mice treated with WTSNF (300 mg/kg). ${ }^{a-d}$ Mean values with different letters in the same bar graph are significantly different $(p<0.05)$ according to Duncan's multiple range test.

damage tissues and organs. D-Gal, which is an agent that interferes with phosphate uridine in liver cells, can cause degeneration and necrosis of liver cells. D-Gal-induced aging is considered to be similar to natural aging in terms of morphology and function. ${ }^{3}$ Exogenous LPS increases the toxicity of D-Gal, and D-Gal causes hypersensitivity to LPS. The physiological function of LPS is manifested by toll-like receptor 4 on the surface of host cell membranes. Through the complex intracellular signaling pathway including NF- $\mathrm{BB}$ pathway, LPS leads to the production of inflammatory cytokines, such as TNF $\alpha$, IL-1, and IL-6, thereby causing systemic inflammation. ${ }^{6}$ Therefore, animal models with D-Gal/LPS-induced chronic oxidative and inflammatory injury can be established. Through the organ index and histology analyses in this study, the main organs of the mice with D-Gal/LPSinduced aging were found to be reduced, with varying degrees of oxidative damage and inflammatory factor infiltration, but WTSNF intervention inhibited this effect.

The liver is the most vigorous metabolic organ of the human body, and it is also an important detoxification organ. It plays an important role in regulating the health of the body. ALT is mainly found in liver cytoplasm, while AST is mainly found in liver cell mitochondria. When liver cells are damaged, serum ALT levels increase, and when liver cells die, serum AST levels increase significantly. ${ }^{26,27}$ Therefore, ALT and AST levels in serum can reflect the degree of liver damage. The serum transaminase detection results showed that ALT and AST levels increased after D-Gal/LPS-induced injury, but WTSNF intervention inhibited these transaminase increases.

In terms of oxidative stress, SOD, GSH-Px, CAT, and other antioxidant enzymes constitute the body's antioxidant defense system. If the body's oxidation and antioxidation systems are out of balance, then it will lead to lipid peroxidation of biofilms, thereby causing extensive cell damage. Hundreds of diseases are related to free radicals, including cardiovascular diseases, cerebrovascular diseases, and tumors, which are some of the most threatening conditions in humans. ${ }^{28,29} \mathrm{MDA}$ is the final product of lipid peroxidation of the cell membrane. It is cytotoxic, 

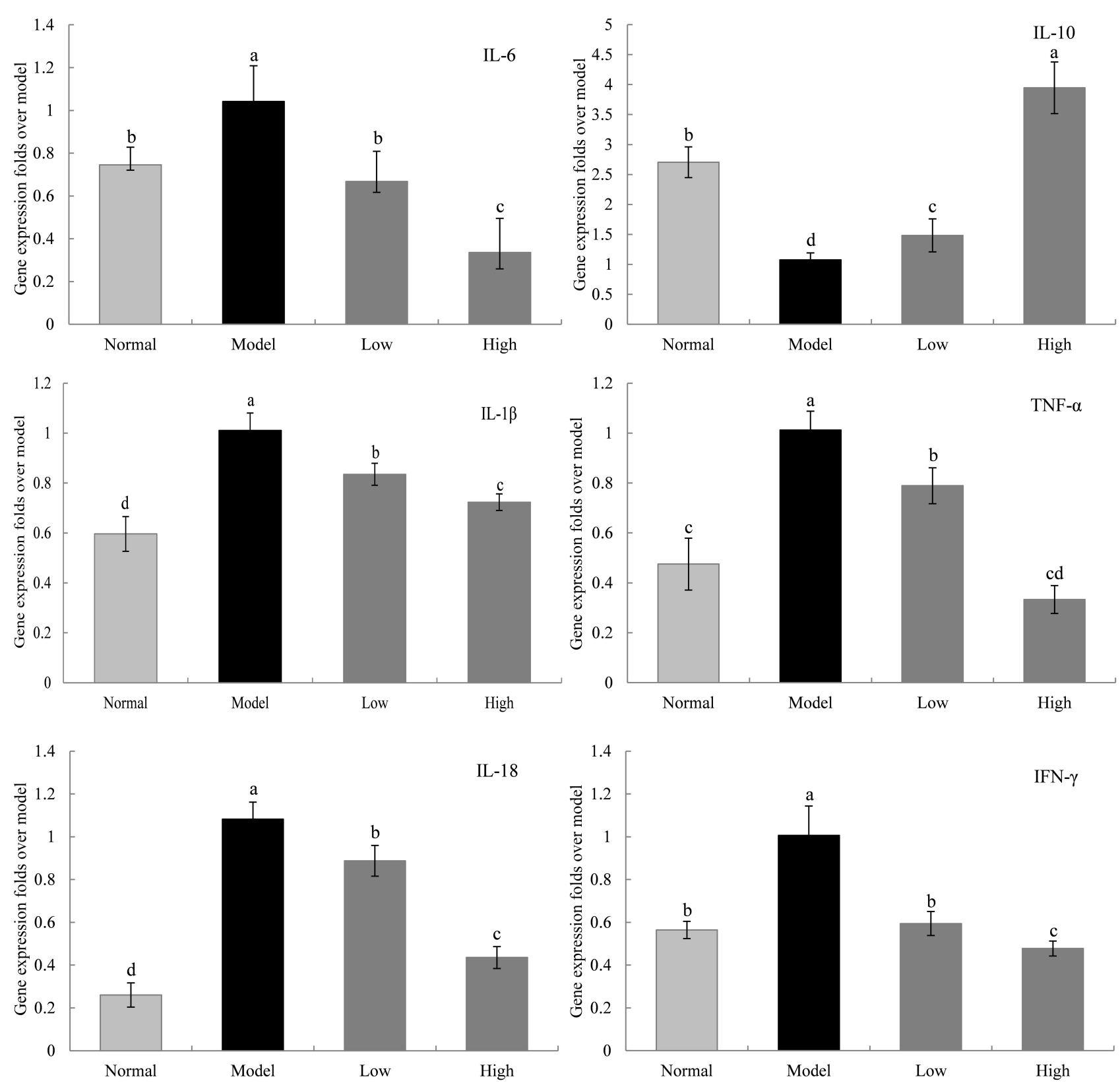

Figure 7 The IL-6, IL-I0, IL-I $\beta$, TNF- $\alpha$, IL- 18 and IFN- $\gamma$ mRNA expression in liver of mice. Model: mice treated with D-Gal (30 mg/kg bw)/LPS (3 $\mu g / \mathrm{kg}$ bw); Low: mice treated with WTSNF (150 mg/kg); High: mice treated with WTSNF $(300 \mathrm{mg} / \mathrm{kg})$. ${ }^{\mathrm{a}-\mathrm{d}}$ Mean values with different letters in the same bar graph are significantly different $(p<0.05)$ according to Duncan's multiple range test.

causing the cross-linking and polymerization of large molecules, such as proteins and nucleic acids. Therefore, the degree of organ damage and trend of the disease can be predicted by measuring changes in MDA indicators in body tissues. ${ }^{30} \mathrm{NO}$, which is a multifunctional biological mediator of cytotoxicity, can be regarded as an indicator of oxidation. Various cells produce NO, and metabolic disorders involving NO promote the occurrence and development of oxidative damage. ${ }^{31}$ The results of this study showed that after D-Gal/LPS-induced injury, the activity levels of SOD, GSH-Px, and CAT in the serum and liver tissue of the mice were significantly reduced, and the content levels of MDA and NO were increased, suggesting that D-Gal/LPS directly triggered the production of a large number of free radicals, thereby causing oxidative stress. After WTSNF intervention, the opposite antioxidant effect was observed that WTSNF inhibited the oxidative stress process to a certain extent. 

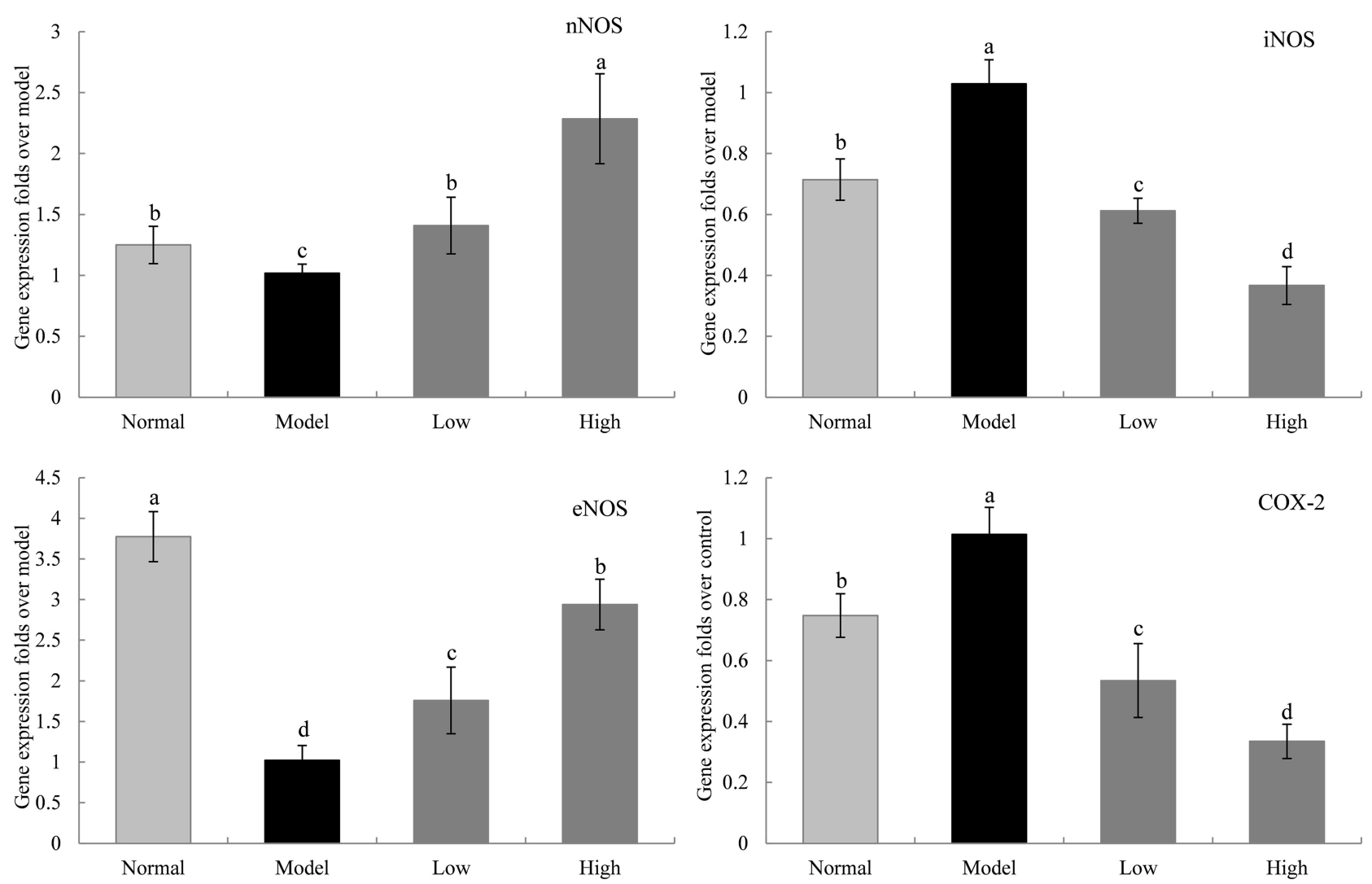

Figure 8 The $\mathrm{nNOS}$, iNOS, eNOS and COX-2 mRNA expression in liver of mice. Model: mice treated with D-Gal ( $30 \mathrm{mg} / \mathrm{kg}$ bw)/LPS ( $3 \mu \mathrm{gg} / \mathrm{kg}$ bw); Low: mice treated with WTSNF (150 mg/kg); High: mice treated with WTSNF $(300 \mathrm{mg} / \mathrm{kg}) .{ }^{\mathrm{a}-\mathrm{d}}$ Mean values with different letters in the same bar graph are significantly different $(p<0.05)$ according to Duncan's multiple range test.

D-Gal/LPS-induced aging in mice not only involves oxidative stress, but also inflammation. IL-6 is a polypeptide with a wide range of biological properties. It acts on a variety of target cells and participates in immune and inflammatory processes. TNF $\alpha$ is mainly produced by activated monocytes, activated macrophages, and various other cells. Its biological properties involve immune regulation, infection, inflammation, tumor suppression, etc. IL-6, which is often co-induced with $\mathrm{TNF} \alpha$, plays a role in a variety of physiological and immune processes, especially in the systemic inflammatory response. ${ }^{32}$ IL-10, which is also known as cytokine synthesis inhibitory factor, can strongly inhibit IL-6 and TNF $\alpha$ at the transcriptional level, thereby having an anti-inflammatory effect. ${ }^{33}$ IL-12, which is produced by B cells and macrophages, is a pro-inflammatory cytokine in the form of a heterodimer. It can induce the production of IFN- $\gamma$ and TNF $\alpha .{ }^{34}$ IFN- $\gamma$ is mainly produced by activated $\mathrm{T}$ cells, which can induce the production of iNOS and promote the synthesis of NO. ${ }^{35}$ IL- $1 \beta$ is mainly produced by monocytes and macrophages. It is expressed in inflammatory injury, and its precursor cell processing depends on caspase- $1 .{ }^{36}$ The results of this study showed that WTSNF significantly reduced the D-Gal/LPS-induced increases in IL-6, IL-12, IL- $1 \beta, T N F \alpha$, and IFN- $\gamma$ levels in the serum and liver tissue, and it increased IL-10 levels. It is speculated that in addition to inhibiting oxidative damage, WTSNF also exerts anti-aging effects through anti-inflammatory effects.

We also analyzed the effects of WTSNF on mice with D-Gal/LPS-induced aging through the expression levels of genes related to oxidation and inflammation. NOS catalyzes the production of NO from L-arginine and molecular oxygen. As an important messenger and effector molecule in organisms, NO is one of the gas messenger molecules closely related to inflammation and oxidative stress. The half-life of NO in the body is short, and its biological function is completely dependent on NOS. Therefore, NOS is a key enzyme for NO synthesis and plays a key role in regulating NO production. NOS is divided into 3 subtypes according to the different regions of production: nNOS, eNOS, and iNOS. Among them, nNOS and eNOS are calmodulin-dependent and mainly exist in neuronal 

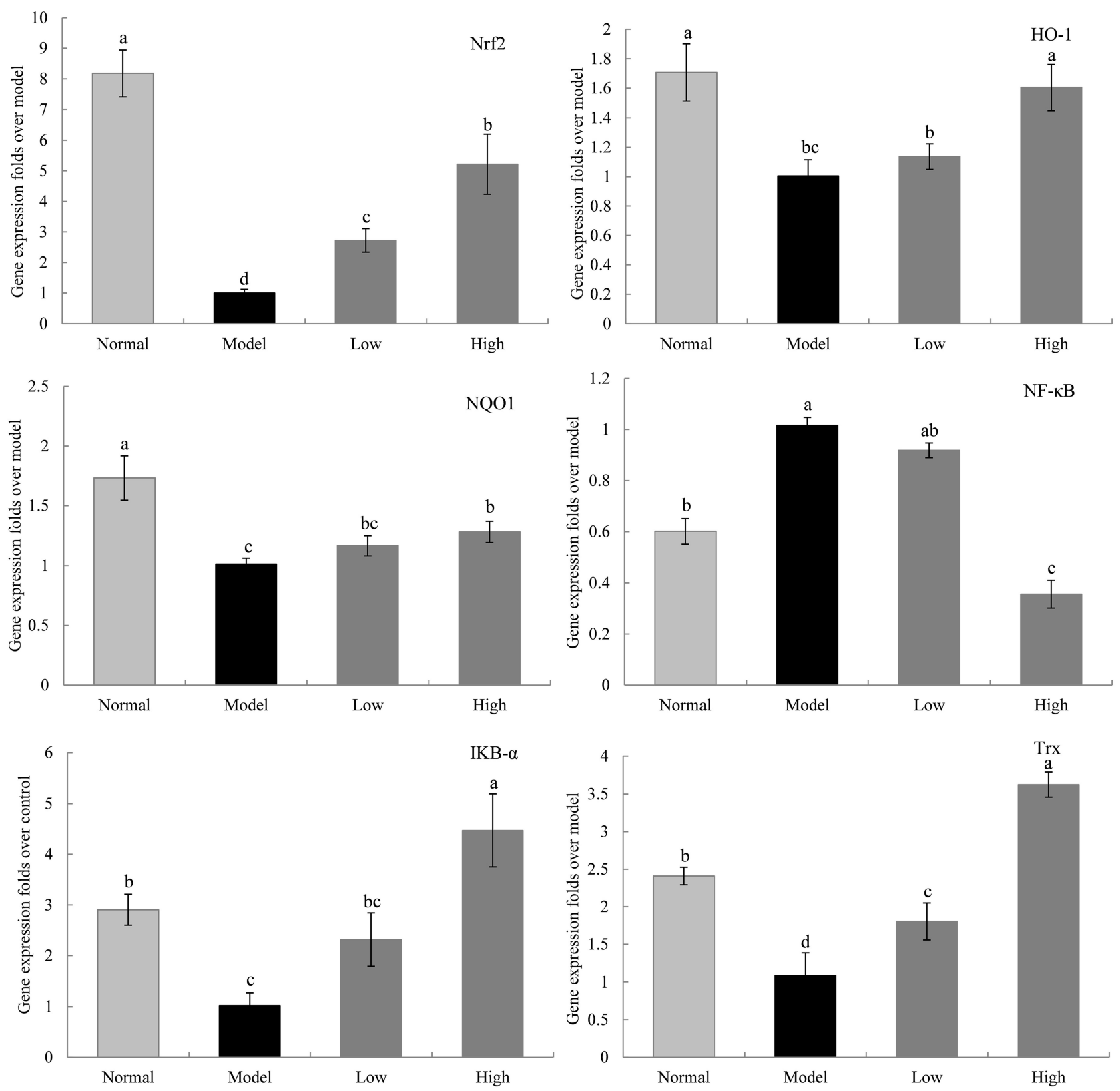

Figure 9 The Nfr2, HO-I, NQOI, NF-kB, IKB- $\alpha$ and Trx mRNA expression in liver of mice. Model: mice treated with D-Gal (30 mg/kg bw)/LPS (3 $\mu$ g/kg bw); Low: mice treated with WTSNF (150 mg/kg); High: mice treated with WTSNF (300 mg/kg). ${ }^{a-d}$ Mean values with different letters in the same bar graph are significantly different $(p<0.05)$ according to Duncan's multiple range test.

cells, endothelial cells, adrenal cortical cells, and platelets.

Calmodulin directly regulates the activity of nNOS and eNOS by regulating calcium ion concentrations in eukaryotic cells. On the other hand, iNOS is non-calmodulin-dependent. It is widely present in mammalian cells, and it does not depend on the regulation of intracellular calcium ion concentrations, but it can be induced by inflammation. ${ }^{37-39}$ COX-2 is an inflammatory factor that can be induced by LPS and produced through the p38 MAPK cascade. Under various acute and chronic inflammatory conditions, macrophages, monocytes, epithelial cells, synovial cells, and cancer cells are all COX-2-positive. ${ }^{40}$ We found that WTSNF increased the expression levels of nNOS and eNOS in injured mice and reduced the expression levels of iNOS and COX-2, thereby inhibiting D-Gal/LPS-induced aging in mice.

Nrf2 is a key molecule to maintain the balance between oxidation and antioxidation in cells. Activating the Nrf2 
signaling pathway can obviously reduce oxidative damage to organs caused by D-Gal/LPS. The results of this study showed that WTSNF activated the Nrf2 signaling pathway and significantly increased the expression levels of $\mathrm{Nrf} 2$ and downstream HO-1 and NQO1. HO-1 is a stress protein, and NQO1 is a flavinase. When expressed, HO-1 and NQO1 each have roles in antioxidative and anti-inflammatory processes. $^{41}$ This study found that D-Gal/LPS induced macrophages to secrete cytokines such as TNF $\alpha$ and IL-6 through the $\mathrm{NF}-\kappa \mathrm{B}$ pathway. In the resting state, $\mathrm{NF}-\kappa \mathrm{B}$ combines with I $\kappa \mathrm{B}-\alpha$ to form a trimer, which exists in the cytoplasm in an inactive form. Under the stimulation of D-Gal/LPS, I $\kappa$ B- $\alpha$ degenerates, and the expression of NF$\kappa \mathrm{B}$ increases. ${ }^{42}$ In this study, WTSNF significantly inhibited the activation of the $\mathrm{NF}-\kappa \mathrm{B}$ pathway induced by D-Gal/LPS and the expression levels of the inflammatory factors TNF $\alpha$ and IL-6; reduced inflammation by blocking the NF- $\kappa$ B pathway; and exerted an anti-inflammatory effect. Furthermore, Trx can directly scavenge reactive oxygen species, such as hydrogen peroxide and oxygen free radicals, in cells, and it can also regulate the redox balance in cells. The Trx system, which is composed of Trx, Trx reductase, and nicotinamide adenine dinucleotide phosphate (NADPH), is an NADPH-dependent disulfide reductase system widely seen in prokaryotes and eukaryotes. This disulfide reductase system plays an important regulatory role in redox balance in the body, as well as in cell proliferation, and WTSNF intervention enhances the expression of $\operatorname{Trx} .^{43}$

\section{Conclusion}

Low and high doses of WTSNF have antioxidative and anti-inflammatory effects. WTSNF can improve organ damage; regulate liver function indexes; increase the levels of antioxidant enzymes and compounds in the serum and liver; reduce peroxide levels; regulate the levels of related immune factors; increase the expression levels of antioxidative and anti-inflammatory genes in the liver; reduce the expression levels of oxidative and pro-inflammatory genes; activate the Nrf2/HO-1 pathway; and inhibit the NF- $\kappa \mathrm{B}$ pathway. In conclusion, WTSNF can improve D-Gal/LPS-induced aging in mice.

\section{Acknowledgments}

This research was funded by the Chongqing University Innovation Research Group Project (CXQTP20033), the Science and Technology Project of the Chongqing Education Commission (KJQN202001604) and Chongqing
Science and Health Joint Medical Research Project (2020MSXM072), China.

\section{Disclosure}

The authors declare no conflicts of interest.

\section{References}

1. Fox P. From senility to Alzheimer's disease: the rise of the Alzheimer's disease movement. Milbank Q. 1989;67(1):58-102. doi: $10.2307 / 3350070$

2. Chung HY, Sung B, Jung KJ, et al. The molecular inflammatory process in aging. Antioxid Redox Signal. 2006;8(3-4):572-581. doi:10.1089/ars.2006.8.572

3. Cui X, Zuo P, Zhang Q, et al. Chronic systemic D-galactose exposure induces memory loss, neurodegeneration, and oxidative damage in mice: protective effects of R-alpha-lipoic acid. $J$ Neurosci Res. 2010;83(3):1584-1590. doi:10.1002/jnr.20845

4. Ho SC, Liu JH, Wu RY. Establishment of the mimetic aging effect in mice caused by D-galactose. Biogerontology. 2003;4(1):15-18. doi:10.1023/A:1022417102206

5. Felices MJ, Escusol S, Martinez-Beamonte R, et al. LPS-squalene interaction on d-galactose intestinal absorption. $J$ Physiol Biochem. 2019;75(3):329-340. doi:10.1007/s13105-019-00682-8

6. Biharee A, Sharma A, Kumar A, et al. Antimicrobial flavonoids as a potential substitute for overcoming antimicrobial resistance. Fitoterapia. 2020;146:104720. doi:10.1016/j.fitote.2020.104720

7. Hilal Y, Engelhardt U. Characterisation of white tea - comparison to green and black tea. J Verbrauch Lebensm. 2007;2(4):414-421. doi:10.1007/s00003-007-0250-3

8. Almajano MP, Vila I, Gines S. Neuroprotective effects of white tea against oxidative stress-induced toxicity in striatal cells. Neurotox Res. 2011;20(4):372-378. doi:10.1007/s12640-011-9252-0

9. Santana-Rios G, Orner GA, Amantana A, et al. Potent antimutagenic activity of white tea in comparison with green tea in the Salmonella assay. Mutat Res. 2001;495(1-2):61-74. doi:10.1016/S1383-5718 (01)00200-5

10. Herrmann K. Flavonols and flavones in food plants: a review. Int $J$ Food Sci Technol. 1976;11(5):433-448. doi:10.1111/j.1365-2621.19 76.tb00743.x

11. Li C, Huang G, Tan F, et al. In vitro analysis of antioxidant, anticancer, and bioactive components of apocynum venetum tea extracts. J Food Qual. 2019;10(56):34289. doi:10.1155/2019/2465 341

12. Thaipong K, Boonprakob U, Crosby K, et al. Comparison of ABTS, DPPH, FRAP, and ORAC assays for estimating antioxidant activity from guava fruit extracts. J Food Compos Anal. 2006;19(6-7):669675. doi:10.1016/j.jfca.2006.01.003

13. Li C, Liu H, Yang J, et al. Effect of soybean milk fermented with Lactobacillus plantarum HFY01 isolated from yak yogurt on weight loss and lipid reduction in mice with obesity induced by a high-fat diet. RSC $A d v$. 2020;10:34276-34289. doi:10.1039/ D0RA06977A

14. Donadu MG, Le NT, Ho DV, et al. Phytochemical compositions and biological activities of essential oils from the leaves, rhizomes and whole plant of hornstedtia bella Škorničk. Antibiotics. 2020;9 (6):334-350. doi:10.3390/antibiotics9060334

15. Chaves-López C, Usai D, Donadu MG, et al. Potential of Borojoa patinoi Cuatrecasas water extract to inhibit nosocomial antibiotic resistant bacteria and cancer cell proliferation in vitro. Food Funct. 2018;9(5):2725-2734. doi:10.1039/c7fo01542a

16. Carloni P, Tiano L, Padella L, et al. Antioxidant activity of white, green and black tea obtained from the same tea cultivar. Food Res Int. 2013;53(2):900-908. doi:10.1016/j.foodres.2012.07.057 
17. Cui W, Fan X, Wang N, et al. Investigation of in vivo and in vitro pharmacokinetic characteristics of Kaji-ichigoside F1 in rats. Nat Prod Commun. 2020;15(3):1-6. doi:10.1177/1934578X20915018

18. Calderon-Montano JM, Burgos-Moron E, Perez-Guerrero C, LopezLazaro MA. Review on the dietary flavonoid kaempferol. Mini Rev Med Chem. 2011;11(4):298-344. doi:10.2174/138955711795305335

19. Boots AW, Haenen GR, Bast A. Health effects of quercetin: from antioxidant to nutraceutical. Eur J Pharmacol. 2008;585(2-3):325337. doi:10.1016/j.ejphar.2008.03.008

20. Bai SC, Gatlin DM. Dietary rutin has limited synergistic effects on vitamin $\mathrm{C}$ nutrition of fingerling channel catfish (Ictalurus punctatus). Fish Physiol Biochem. 1992;10(3):183-188. doi:10.1007/BF0000 4512

21. Gau HP. Experience with Lespenephryl and Lespenephryl-forte in the treatment of chronic kidney insufficiency. Med Welt. 1969;44:24262428.

22. Boesch-Saadatmandi C, Loboda A, Wagner AE, et al. Effect of quercetin and its metabolites isorhamnetin and quercetin-3-glucuronide on inflammatory gene expression: role of miR-155. J Nutr Biochem. 2011;22(3):293-299. doi:10.1016/j.jnutbio.2010.02.008

23. Shen YC, Chiou WF, Chou YC, et al. Mechanisms in mediating the anti-inflammatory effects of baicalin and baicalein in human leukocytes. Eur J Pharmacol. 2003;465(1-2):171-181. doi:10.1016/S00 14-2999(03)01378-5

24. Wang GH, Tang HP, Peng MJ, et al. Study on the antioxidant and antimicrobial activities of four flavonol compounds from Alpinia Officinarum Hance rhizome in vitro. Food Machine. 2017;33 (5):168-172. doi:10.13652/j.issn.1003-5788.2017.05.034

25. Hardbower DM, De Sablet T, Chaturvedi R, et al. Chronic inflammation and oxidative stress. Gut Microbes. 2013;4(6):475-481. doi:10. 4161/gmic. 25583

26. Mihas AA, Gibson RG, Mihas TA, et al. Sensitivity of serum glutamic oxaloacetic transaminase and bile acid levels for the detection of experimental liver injury in rats. $J$ Med. 1981;12(4):237-242. doi:10.1084/jem.153.6.1690

27. Ozer JS, Chetty R, Kenna G, et al. Enhancing the utility of alanine aminotransferase as a reference standard biomarker for drug-induced liver injury. Regul Toxicol Pharmacol. 2010;56(3):237-246. doi:10. 1016/j.yrtph.2009.11.001

28. Ceballos-Picot I, Witko-Sarsat V, Merad-Boudia M, et al. Glutathione antioxidant system as a marker of oxidative stress in chronic renal failure. Free Radic Biol Med. 1996;21(6):845-853. doi:10.1016/ 0891-5849(96)00233-x

29. Monk LS, Fagerstedt KV, Crawford RM. Oxygen toxicity and superoxide dismutase as an antioxidant in physiological stress. Physiol Plant. 1989;76(3):456-459. doi:10.1111/j.1399-3054.1989.tb06219.x

30. Olatunji OJ, Chen H, Zhou Y. Neuroprotective effect of trans-Ncaffeoyltyramine from Lycium chinense against $\mathrm{H}_{2} \mathrm{O}_{2}$ induced cytotoxicity in $\mathrm{PC} 12$ cells by attenuating oxidative stress. Biomed Pharmacother. 2017;93:895-902. doi:10.1016/j.biopha.2017.07.013
31. Bhandari V, Choo-Wing R, Chapoval S, et al. Essential role of nitric oxide in VEGF-induced, asthma-like angiogenic, inflammatory, mucus, and physiologic responses in the lung. Proc Natl Acad Sci U S A. 2006;103(29):11021-11026. doi:10.1073/pnas.0601057103

32. Zhang LG, Wu T, Olatunji OJ, et al. $\mathrm{N}^{6}$-(2-hydroxyethyl)-adenosine from Cordyceps cicadae attenuates hydrogen peroxide induced oxidative toxicity in PC12 cells. Metab Brain Dis. 2019;34(5):13251334. doi:10.1007/s11011-019-00440-1

33. Eddie I, Hoshi N, Shouval DS, et al. Anti-inflammatory effect of IL10 mediated by metabolic reprogramming of macrophages. Science. 2017;356(6337):513-519. doi:10.1126/science.aal3535

34. Fukao T, Matsuda S, Koyasu S. Synergistic effects of IL-4 and IL-18 on IL-12-dependent IFN- $\gamma$ production by dendritic cells. J Immunol. 2000;164(1):64-71. doi:10.4049/jimmunol.164.1.64

35. Nirschl CJ, Suárez-Fariñas M, Izar B, et al. IFN $\gamma$-dependent tissueimmune homeostasis is co-opted in the tumor microenvironment. Cell. 2017;170(1):127-141. doi:10.1016/j.cell.2017.06.016

36. Wang F, Wang $\mathrm{K}, \mathrm{Xu} \mathrm{W}$, et al. SIRT5 desuccinylates and activates pyruvate kinase M2 to block macrophage IL-1 $\beta$ production and to prevent DSS-induced colitis in mice. Cell Rep. 2017;19(11):23312344. doi:10.1016/j.celrep.2017.05.065

37. Alderton WK, Cooper CE, Knowles RG. Nitric oxide synthases: structure, function and inhibition. Biochem J. 2001;357(3):593-615. doi:10.1042/0264-6021:3570593

38. Donadu M, Usai D, Pinna A, et al. In vitro activity of hybrid lavender essential oils against multidrug resistant strains of Pseudomonas aeruginosa. J Infect Dev Ctries. 2018;12(1):9-14. doi:10.3855/jidc. 9920

39. Trong N, Donadu MG, Ho DV, et al. Biological activities of essential oil extracted from leaves of Atalantia sessiflora Guillauminin Vietnam. J Infect Dev Ctries. 2020;14(9):1054-1064. doi:10.3855/ jidc. 12469

40. Tambewagh UU, Kandhare AD, Honmore VS, et al. Anti-inflammatory and antioxidant potential of Guaianolide isolated from Cyathocline purpurea: role of COX-2 inhibition. Int Immunopharmacol. 2017;52:110-118. doi:10.1016/j.intimp.2017.09.001

41. Zhang H, Liu YY, Jiang Q, et al. Salvianolic acid A protects RPE cells against oxidative stress through activation of $\mathrm{Nrf} 2 / \mathrm{HO}-1$ signaling. Free Radic Biol Med. 2014;69:219-228. doi:10.1016/j. freeradbiomed.2014.01.025

42. Lawrence T. Factor NF- B pathway in inflammation. Cold Spring Harb Perspect Biol. 2009;1(6):a001651-a001651. doi:10.1101/ cshperspect.a001651

43. Hirasawa M, Schürmann P, Jacquot JP, et al. Oxidation-reduction properties of chloroplast thioredoxins, ferredoxin: thioredoxin reductase, and thioredoxin f-regulated enzymes. Biochemistry. 1999;38 (16):5200-5205. doi:10.1021/bi982783v

\section{Publish your work in this journal}

Drug Design, Development and Therapy is an international, peerreviewed open-access journal that spans the spectrum of drug design and development through to clinical applications. Clinical outcomes, patient safety, and programs for the development and effective, safe, and sustained use of medicines are a feature of the journal, which has also been accepted for indexing on PubMed Central. The manuscript management system is completely online and includes a very quick and fair peer-review system, which is all easy to use. Visit http://www. dovepress.com/testimonials.php to read real quotes from published authors. 